\title{
Distriktslege på Helgelandskysten for 60 år siden
}

\author{
I 1948 dro jeg som distriktslege til \\ Helgelandskysten. Det ble et møte \\ med vakker natur og en hardfør og \\ raus befolkning og med arbeid under \\ helt andre forhold enn i dag.
}

Basert på et foredrag på Eldre lægers forenings årsmøte på Soria Moria 8. -9.11. 2009.

Søren Christian Sommerfelt

Lønnegloveveien 44

3230 Sandefjord

Ved slutten av studiet høsten 1947 fikk kullet beskjed om at 15 distriktslegevikariater måtte besettes, eventuelt ved beordring. (Dette var jo mange år før turnusordningen ble innført.) I motsetning til de fleste andre på kullet ønsket jeg meg et sted langt vekk fra mitt bosted (Oslo, nygift uten barn), og jeg valgte Meløy, et kystdistrikt i Nordland. Min sjøerfaring besto av kajakkturer i indre Oslofjord, seiling med oselver (spriseil) på Eftang og noen turer med Skibladner. Det året fikk jeg rikelig i tillegg.

Alle som skulle ut i distriktsstilling, gruet seg til tanntrekninger, og for i alle fall å lære litt gikk jeg noen få dager på Tannlegehøyskolen. Min første pasient i Meløy var en liten, gammel mann: «Æ skulle ha trekt e tajn.» Det viste seg å være enkelt, det var bare én igjen, og den var løs. Senere ble det verre, men fordi det var en tannlege nord i distriktet, nektet jeg flere ganger å trekke tenner på yngre mennesker. Distriktslegen var førstevalget fordi da var det refusjon fra trygdekassen; dette gjaldt ikke tannlegen.

\section{Avhengig av båt}

Vi tok hurtigruten til Grønøy og båtskyss til Vallsjøen. Boligen var stor, med kontor, venteværelse og et lite apotekrom samt boligdel med stue, spisestue og kjøkken nede og fire soverom og bad oppe. Nærmeste nabo var menighetshuset (med trampeorgel som min kone brukte) ca. $1 \mathrm{~km}$ unna og ytterligere $1 \mathrm{~km}$ til et bolighus. Familien der ble vi godt kjent med.

Nord i kommunen var det bilvei fra Glomfjord forbi Ørnes og inn i Gildeskål. Ellers var det flere korte veistumper med en bil eller to, men de hang ikke sammen så man var helt avhengig av båt. Legekoffert, dress og sko? Glem det. Ryggsekk, knickers og gummistøvler.

«Sprøyt» var bygd som en skyssbåt, $36 \times 12$ fot med ensylindret Wickman glødehodemotor og gjorde opptil 7 knop! Den smale båten med rikelig bly i kjølen var veldig rank og eneste mann om bord, Edvard, turde ikke gå med vinden aktenom tvers, så vi krysset med vinden - ren sidevind eller rett bakfra. Kahytten hadde benker og en liten parafinkomfyr samt en køye på hver side akter med gode kanter så

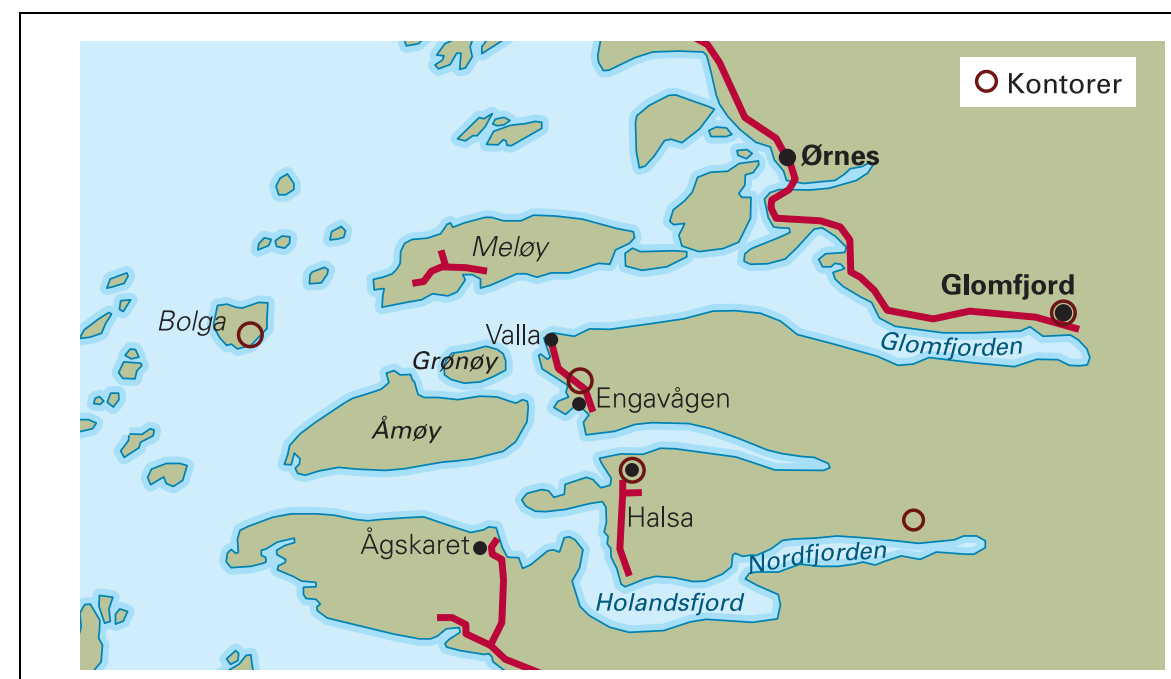

Meløy og omland med de forskjellige kontorstedene avmerket man kunne ligge og lese. Mobiltelefon fantes ikke, så i båten var jeg relativt trygg for å bli kontaktet, men jeg ble ofte prajet for sykebesøk på hjemtur. Alle i distriktet kjente doktor'ns faste reiseruter, og damene på telefonsentralen hadde for øvrig god oversikt over hvor jeg var.

Arbeidsuken var som følger: Mandag og onsdag var det kontordag hjemme på Vall fra kl 9 til venteværelset var tomt. Pasientene kom gjerne flere sammen i båt. Det var alltid spennende å se ut av vinduet hvor store båtlastene var. Tirsdag og fredag var det kontordag i Haugvik, hvor Hydro bygde ny fabrikk, og deretter i selve Glomfjord. Det var $13 / 4$ times båtreise hver vei så jeg fikk lest en del fag, men i skikkelig ruskevær, som det ble mye av utover høsten, sto jeg oppe i styrehuset. Torsdager hadde jeg utekontordag på forskjellige steder i distriktet. Kontorene var stort sett i private hjem. I stuen hos Simon og Andrea, som hadde hjemmekontoret i Nordfjord, ble dagen alltid avsluttet med hvit duk, smørbrød og kaker, og melk med rikelig fløte oppi som drikke til denne rare doktor'n som ikke drakk kaffe! Fløten skulle jeg gjerne ha unnvært, men hadde ikke hjerte til å si det. Lørdager var det kontorarbeid, skolebarnsundersøkelse, besøk på sykehjem og aldershjem.

Vi kunne stort sett legge til kai der kontordagene fant sted, men i sykebesøk måtte jeg nesten alltid i småbåten og selv ro til land. Edvard fant alltid frem ute i «værran» selv i stupende mørke. Han forklarte meg hvor på stranden jeg skulle trekke opp prammen og i hvilken retning jeg skulle gå for å finne huset, uten strøm. Jeg ble alltid glad når jeg fikk se lys fra vinduene.

En vinterdag ble jeg tilkalt på sykebesøk til en gård innerst i Nordfjorden av Holandsfjord. Etter $21 / 2$ times båtreise rodde jeg til land, spente på meg skiene og dro oppover bjerkelia en halv times tid. Mannen på gården hadde en svær kruppøs pneumoni, og jeg ga ham det nye vidundermidlet penicillin som jeg alltid hadde i ryggsekken. Det var en tykk oljesuspensjon som skulle settes dypt intramuskulært i «ytre, øvre kvadrant», og det krevdes betydelige krefter både å fylle spøyten og å injisere! Det var geografisk umulig å fortsette penicillinbehandlingen, så jeg ville fortsette med sulfatiazol i tablettform. Det hadde jeg nede i båten så jeg spurte om en fra gården kunne bli med ned 


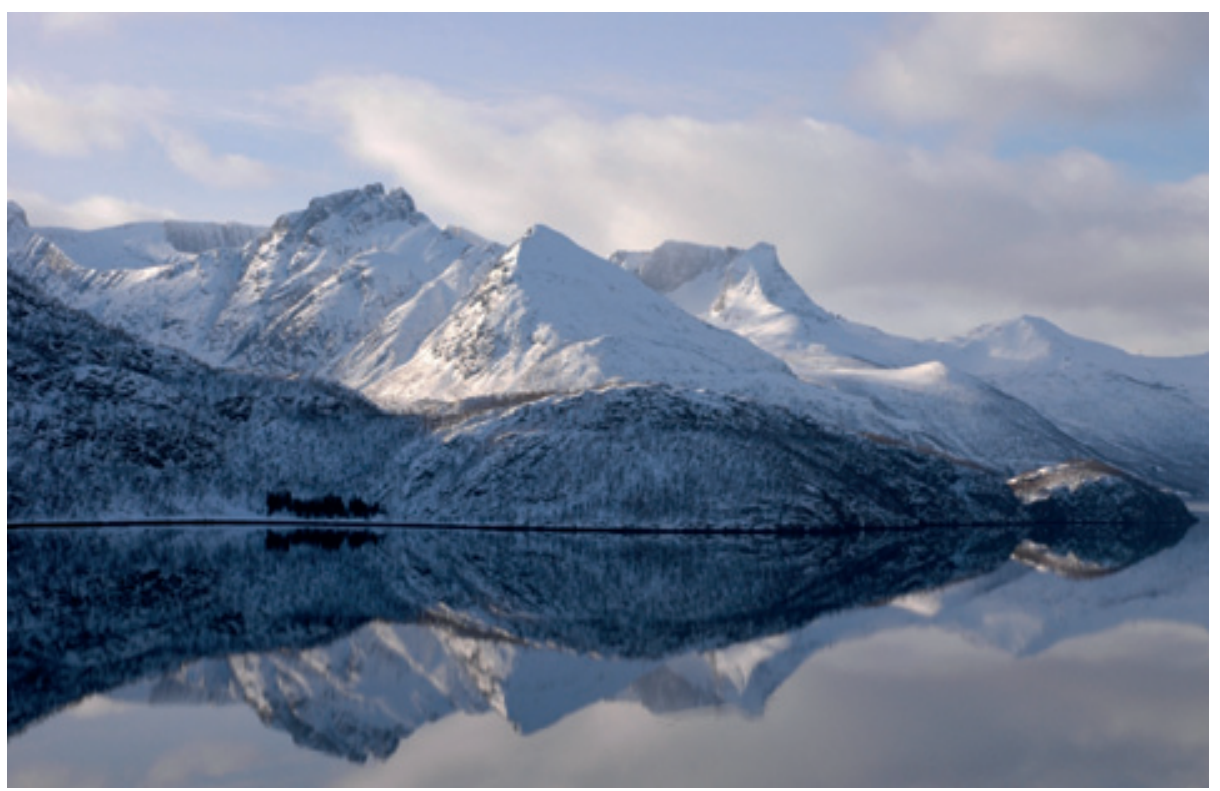

for å få tablettene. «Jeg kan komme ned,» sa kona i 60-årene. Jeg spente på meg skiene, men hun tok det helt med ro. Vel, tenkte jeg, da kjører jeg i forveien og făr heller vente der nede. Da jeg kom ned, sto hun på stranden i kjole og kalosjer - og ski - og ventet på meg. Hun hadde kjørt en snarvei!

\section{Hardfør befolkning}

Trygdekassekassereren ble ansett for å være svært påholden, og han spurte meg en gang om jeg ikke reiste i mange unødvendige sykebesøk. «Jo,» svarte jeg, «men at det er unødvendig, er det bare jeg som kan avgjøre når jeg er der.» Dog hadde vi en gang en lang tur ut til en øy, og pasientens vesentligste bekymring var om hun burde reise i sykekurv eller bare med følge når hun skulle til innleggelse på Sandnessjøen sykehus om noen dager. Det tror jeg var den eneste gangen jeg tok fullt mellomlegg av en pasient ved sykebesøk!

En sen kveld da jeg kom hjem fra Glomfjord, satt det et eldre ektepar og ventet på meg i stuen. Han hadde rodd over sundet fra Meløy, ca. $1 / 2$ time, fordi han var blitt litt tungpusten. Det var komplett dempning og blåselyd over hele den ene lungen. Han fikk penicillinsprøyte og sulfapreparat og beskjed om at kona skulle ro hjem! Noen tid senere var han på storseifiske i småbåten hjemmefra, kom hjem med den ene hånden på ryggen og spurte datteren om å få en tang. Han snudde seg og forsøkte tydeligvis å rykke noe løs, fortalte hun meg senere. Det gikk ikke, så han rodde alene inn til doktoren. Han hadde en vanlig, svær seiangel godt festet $i$ hånden, og da jeg så nærmere i såret (lokalbedøvelse ville han ikke ha noe av), så jeg at kroken lå rundt tommelfingersenen, og den hadde han (heldigvis) ikke greid å ryke av. For meg var det lett å løfte senen over agnoren og sy noen sting. 25-30 år senere leste jeg i avisen av han hadde klippet båndet for en ny vei på Meløy; da var han 104 år gammel.

En dag etter en kontordag på Bolga ba jordmoren meg vente til en fødsel i nabohuset var over. Den fødende, en mager 35-åring, hadde fem jenter fra før. Ungen kom greit og jordmor sa: «Det ble en jente»! «Men den sjuende skal bli glunt!» svarte det fra sengen.

\section{Arbeidsoppgavene}

Skolebarnsundersøkelse hørte med blant arbeidsoppgavene. På en liten skole med til sammen ca. 15 elever fortalte læreren at barna fikk tran på skolen. Jeg spurte hvordan han ordnet med oppvasken av transkjeene. «Transkjeer?» svarte han, «vi har ingen.» Barna satt ved pultene, gapte med hodet bakover og fikk tranen helt direkte fra flasken. Meget hygienisk. En lørdag kom jente og hilste meg. Jeg spurte hvor læreren var. «Det er meg det,» sa hun. Hun hadde gått ut av sjuende klasse året før.

Spebarnskontroll var en annen oppgave. En mor kom med sitt 3-4 måneder gamle barn som så vidt hadde gjenvunnet fødselsvekten. Moren hadde for lite melk og barnet fikk byggsuppe som tillegg. «Men barnet skal jo ha melkeblanding.» «Vi har ingen kuer på øya.» Min oppgave ble å skaffe tørrmelk fra Bodø. Noe slikt hadde vi ikke lært om i studietiden og heller ikke at distriktslegen måtte kjenne rutetidene for sørog nordgående hurtigrute hvis en pasient skulle raskt på sykehus. Meløy lå midt mellom Sandnessjøen og Bodø så båten avgjorde sykehusvalget. Overlege Nils Friis (1880-1968) i Bodø var kanskje mest populær; mange pasienter fortalte at «jeg lå under han Friis»».

\section{Farlige sjøreiser}

Tre ganger i løpet av året var Edvard redd. En ung førstegangsgravid hadde en uteblitt jeg til en enda mindre skole. Utenfor sto en abort (missed abortion) og vi kjørte henne til Bodø med doktorbåten denne vinterdagen. Mens vi var der, økte vinden til kuling fra nordvest, «Sprøyt» hev seg skikkelig på hjemturen, og plutselig røk ledningen til lanternene så vi kjørte uten lys i skipsleden. Da gjaldt det å holde utkikk.

En annen gang med kuling fra vest rett inn Glomfjorden fikk vi melding om at en stor tømmerkai var revet løs og drev innover. Båten stampet seg frem i den grove sjøen, og det hadde vært farlig å treffe en vasstrukken gammel kai som lå og duppet i vannskorpen. Det gikk bra.

Tredje gang var en kald vinterdag med kontordag i Holandsfjord. Da jeg var ferdig og gikk ned til sjøen, lå isen innenfor Nordfjorden som et speil. «Sprøyt» hadde ikke ishud, og den harde isen ville virket som en sag i baugen. Edvard visste råd. «Du făr stå i småbåten og bryte,» sa han. Stående i den vesle prammen, håndgikk jeg fremover i relingen til baugen og sto der og vippet prammen opp og ned så isen ble brudt. Det tok nærmere to timer før vi var ute i den isfrie Holandsfjorden.

Da den første pasienten kom for å bli «blåst», altså få opprettholdt pneumothorax, følte jeg meg ikke høy i hatten, men den 20 år gamle mannen hadde lang erfaring og ga meg god rettledning. Senere kom det mange flere.

\section{Nye tider}

Innbyggertallet i Meløy er nå ca. 6 600, en økning på ca. $30 \%$ fra den gang, men nå er det seks leger + to turnusleger, og de kan bile «tørrskodd» over hele distriktet. For å komme ut til øyene har de båt med fullt innredet kontor; den gjør 20 knop!

Oppgitte interessekonflikter: Ingen

Manuskriptet ble mottatt 19.2. 2010 og godkjent 14.5. 2010. Medisinsk redaktør Anne Kveim Lie. 